NBER WORKING PAPER SERIES

\title{
HEALTH INSURANCE COVERAGE AND THE MACROECONOMY
}

\author{
John Cawley \\ Kosali I. Simon \\ Working Paper 10092 \\ http://www.nber.org/papers/w10092
}

\author{
NATIONAL BUREAU OF ECONOMIC RESEARCH \\ 1050 Massachusetts Avenue \\ Cambridge, MA 02138
}

November 2003

We thank Shailesh Bandhari, David Cutler, Alan Garber, Jeanne Lambrew, Linda Loubert, Catherine McLaughlin, Mark Pauly, and conference and seminar participants for their helpful comments. We thank Justine Lynge for editorial assistance. We gratefully acknowledge financial support from the Economic Research Initiative on the Uninsured and the Bronfenbrenner Life Course Center Innovative Research Program. Simon gratefully acknowledges support from a W.E. Upjohn Institute mini-grant. The views expressed herein are those of the authors and not necessarily those of the National Bureau of Economic Research.

(C2003 by John Cawley and Kosali I. Simon. All rights reserved. Short sections of text, not to exceed two paragraphs, may be quoted without explicit permission provided that full credit, including (C) notice, is given to the source. 
Helath Insurance Coverage and the Macreconomy

John Cawley and Kosali I. Simon

NBER Working Paper No. 10092

November 2003

JEL No. I10, J3, J6, E32

\section{$\underline{\text { ABSTRACT }}$}

The primary objective of this paper is to improve our understanding of the historic relationship between state and national macroeconomic climate and the health insurance coverage of Americans. The secondary objective of this paper is to use the historic findings to estimate how the number of uninsured Americans changed during the 2001 recession, and to estimate whether to date enough people have gained health insurance during the current recovery to offset the losses during the recession.

We conclude that the macroeconomy (measured by state unemployment rate and real gross state product) is correlated with the probability of men's health insurance coverage and that this correlation is only partly explained by changes in men's employment status. Counter-cyclical health insurance programs such as Medicaid and the State Children's Health Insurance Program seem to ensure that the health insurance coverage of women and children is insulated from macroeconomic changes. We estimate that 851,000 Americans, the vast majority of whom were adult men, lost health insurance due to macroeconomic conditions alone during the 2001 recession.

John Cawley

134 MVR Hall

Department of Policy Analysis and Management Cornell University

Ithaca, NY 14853

and NBER

jhc38@cornell.edu
Kosali I. Simon

106 MVR Hall

Department of Policy Analysis and Management Cornell University

Ithaca, NY 14853

and NBER

kis6@cornell.edu 


\section{Introduction}

In March 2001, the longest economic expansion in U.S. history ended, and an economic recession began that lasted until November of $2001 .^{2}$ The primary objective of this paper is to improve our understanding of the historic relationship between state and national macroeconomic climate and the health insurance coverage of Americans. The secondary objective of this paper is to use the historic findings to estimate how the number of uninsured Americans changed during the 2001 recession, and to estimate whether enough people have gained health insurance during the current recovery to offset the losses during the recession.

When thinking of how the macroeconomy may affect the probability of health insurance coverage, it is useful to consider the ways in which Americans receive health insurance coverage. Data from the 2001 Current Population Survey (CPS) indicate that 50 percent of adult Americans receive health insurance through their employer, and an additional 19 percent receive it through the employer of a parent or spouse. Six percent of Americans purchase individual health insurance coverage, 4 percent are covered by Medicaid, 4 percent receive it through some other source, and 18 percent are uninsured. ${ }^{3}$ The macroeconomy may affect the probability of coverage through each of these sources. For example, there are several ways that a poor economy may result in the loss of employer-provided coverage. Those who lose their jobs during recession are likely to lose any health insurance previously provided by that employer. Although the Consolidated Omnibus Budget Reconciliation Act of 1985 (COBRA) allows eligible

\footnotetext{
${ }^{2}$ Business Cycle Dating Committee, National Bureau of Economic Research (2003).

${ }^{3}$ Lambrew (2001), Appendix Table 1.
} 
unemployed workers to temporarily purchase health insurance through their former employers, ${ }^{4}$ take-up rates under COBRA are low. ${ }^{5}$ In the majority of cases, the loss of employment results in the loss of any health insurance the worker received through that employer. However, some who lose their jobs remain covered by insurance provided by a spouse's employer. Overall, 44 percent of those who lose their job become uninsured as a result. ${ }^{6}$

A poor macroeconomy can reduce health insurance coverage even among those who remain employed. Employers may cease offering health insurance in order to cut costs in the face of falling profits. Alternatively, employers may reduce their contributions and shift health insurance costs to employees, causing some of those workers to decline coverage. In addition, previously full-time workers may be shifted to part-time jobs that no longer qualify for health insurance benefits.

A poor macroeconomy may lead state governments to reduce eligibility for publicly provided health insurance. Medicaid spending is a large share of state budgets (it represents 19.6 percent of total state spending ${ }^{7}$ ) so when state tax revenues fall because of an economic downturn, there is increased pressure to cut Medicaid budgets, potentially increasing the number of Medicaid-eligible individuals left without coverage. State governors proposed numerous cuts in response to the 2001 recession, including cuts

\footnotetext{
${ }^{4}$ COBRA stipulates that those who recently worked at firms with more than 20 employees have the option of continuing in their employer's health insurance plan for up to 18 months by paying (at most) 102 percent of the full premium for active employees. The Commonwealth Fund 2001 Health Insurance Survey found that 65 percent of current workers would be eligible for COBRA if they became unemployed; see Doty and Schoen (2001).

${ }^{5}$ Only 20 to 25 percent of those eligible for COBRA exercise the option to extend their health insurance coverage; see Rice (1999). The most common explanation for the low take-up rate is cost; on average families pay annual premiums of $\$ 7,200$ for coverage through COBRA, which represents up to two-thirds of the average worker's unemployment check; see Lambrew (2001).

${ }^{6}$ Bennefield (1998).

${ }^{7}$ National Association of State Budget Officers (2002).
} 
in payments to providers. ${ }^{8}$ Those covered by the State Children's Health Insurance Plan (SCHIP) may also be vulnerable to state budget cuts. Medicaid and SCHIP cover 15 percent of unemployed women and 53 percent of children with unemployed parents. ${ }^{9}$

Two factors add to the current pressure on state governments to cut public health insurance programs: first, many states increased eligibility for public health insurance during the 1990s when state budget prospects were brighter, and second, health care costs appear to be increasing as a fraction of GDP after nearly nine years of stability. ${ }^{10}$

A poor macroeconomy may also affect the number of uninsured if those who previously purchased private health insurance become unable to afford it. On the other hand, some people might gain health insurance coverage during bad macroeconomic times if their incomes fall to a level that qualifies for Medicaid.

Policymakers should be concerned about the loss of health insurance coverage for several reasons. First, some who lose employer provided health insurance will join the rolls of publicly provided health insurance such as Medicaid and SCHIP, increasing the strain on the budgets of those programs. Second, uninsured persons may receive less medical treatment than the insured. ${ }^{11}$ Third, uninsured persons may impose costs on the health care system by receiving their care in relatively inefficient ways, such as using the emergency room for conditions that could have been treated with an office visit. ${ }^{12}$

\footnotetext{
${ }^{8}$ Pear and Toner (2002).

${ }^{9}$ Lambrew (2001).

${ }^{10}$ Levitt et al. (2002).

${ }^{11}$ Doyle (2001) exploits auto accidents as natural experiments and finds that auto accident victims who were uninsured received 20 percent less treatment and had 37 percent higher mortality than those who were insured.

${ }^{12}$ Weissman, Gastonis, and Epstein (1992).
} 
Fourth, uninsured individuals are at risk of severe financial loss, including bankruptcy, in the event of illness. ${ }^{13}$

The long economic expansion of the 1990s followed by the 2001 recession and the current recovery raise the question: what is the relationship between macroeconomic climate and health insurance coverage in the U.S. population? Our research will answer that question, plus these others: How does the effect of the macroeconomy on insurance coverage differ for men, women and children? What aspects of the macroeconomy matter: national recession, state unemployment rate, or real per capita gross state product? Does the macroeconomic climate primarily affect rates of uninsurance through changes in employment?

Our results indicate that increases in unemployment rate are negatively correlated, and increases in gross state product are positively correlated, with the probability of coverage for adult men. A substantial fraction, but not all, of this correlation is explained by changes in employment status. In contrast, the insurance coverage of women and children appears to be insulated from macroeconomic fluctuations by public health insurance programs like Medicaid and SCHIP.

We use our results to estimate the number of people who lost health insurance during the 2001 recession, and estimate whether enough people have gained health insurance during the current recovery to offset those losses. We emphasize that our results measure the number of people who lost (or gained) health insurance due solely to macroeconomic factors. Our results indicate that roughly 851,000 Americans (the vast majority of whom were adult men) lost health insurance during the 2001 recession. We

\footnotetext{
${ }^{13}$ Jacoby, Sullivan, and Warren (2000) find that 45.6 percent of persons filing for bankruptcy either incurred at least $\$ 1,000$ in medical bills not covered by insurance or listed illness or injury as the reason for filing for bankruptcy.
} 
estimate that 616,000 Americans gained health insurance coverage between the end of the recession in November 2001 and August 2003. This implies that, as a result of the changing macroeconomy, 235,000 fewer Americans had health insurance coverage in August of 2003, almost two years after the end of the recession, than had coverage in March 2001 when the recession began.

\section{Related Literature}

The United States Bureau of Census, through its Current Population Reports, publishes estimates of the number of uninsured in the U.S. For example, Mills (2002) estimates that 1.4 million Americans lost health insurance during calendar year 2001, and Mills and Bhandari (2003) estimate that 2.4 million Americans lost coverage during 2002. These estimates include changes in insurance status for any reason, whereas this paper focuses on those due to changing macroeconomic conditions.

The Current Population Reports estimates are based on data from the Current Population Survey (CPS) Annual Demographic Supplement. The CPS records whether the respondent was covered by health insurance at any point in the last twelve months; thus, one cannot use the CPS to determine health insurance coverage in a specific month. This limitation of the CPS questions about health insurance is especially acute because the 2001 recession lasted less than a year. As an extreme example, suppose every insured person in the U.S. lost their health insurance during the 2001 recession, and then regained it as soon as the recession was over. Not a single one of those losing health insurance would be recorded as such in the CPS, because each would report that he or she had been covered at some point in the past twelve months. 
Most studies investigating determinants of insurance status include macroeconomic variables such as state unemployment rate as control variables, but the coefficients on these variables are not the focus of the study and are rarely discussed at any length in the text. Only a few studies focus on the link between macroeconomic conditions and health insurance coverage. A Kaiser Family Foundation brief studied aggregate March CPS data for 1980-2000 and found that every percentage point rise in unemployment was associated with an increase of 1.2 million uninsured persons. ${ }^{14} \mathrm{~A}$ study by Holahan and Garrett (2001) that is based on Ku and Garrett (2000) estimates that a percentage point increase in unemployment is associated with a rise in Medicaid enrollment of 1.5 million. Marquis and Long (2001) find mixed evidence that county unemployment rates are correlated with employer offers of health insurance and employer contributions to health insurance. They find that employers are more likely to offer health insurance in tight labor markets in 1993 but cannot reject the hypothesis of a zero correlation in 1997. They also find, contrary to their prediction, that the employer's contribution to employee health insurance is positively correlated with county unemployment rate. Using a variety of data including the CPS, Gilmer and Kronick (2001) estimate that if health expenditures grow twice as fast as personal income over next decade, the percent of the population under age 65 that is uninsured would rise from 16 percent to 21 percent.

Glied and Jack (2003) study how macroeconomic conditions, income, and health care costs are correlated with insurance coverage across education groups using statelevel CPS data. They find that unemployment rates are more strongly correlated with

\footnotetext{
${ }^{14}$ Gruber and Levitt (2002).
} 
insurance coverage for well-educated workers, in part because workers with less education are at all times less likely to be offered employer-provided health insurance.

A limitation of several of these previous studies is their use of the CPS data, which, as mentioned before, cannot indicate health insurance coverage in a particular month, making it impossible to relate health insurance coverage to macroeconomic conditions at a specific point in time. A contribution of this paper is to provide estimates derived from reports of health insurance coverage in a specific month matched with macroeconomic conditions during that month, using data from the Survey of Income and Program Participation (SIPP).

The previous literature is also limited by its use of cross-sectional data and inability to remove unobserved time-invariant heterogeneity. This is a particular problem if the populations of high-unemployment states differ from those in low-unemployment states in unobserved ways that affect the probability of health insurance coverage; such unobserved heterogeneity would result in biased estimates of the effect of macroeconomic conditions on health insurance coverage. This paper contributes to the literature by analyzing longitudinal data on individuals and by controlling for personspecific fixed effects. Our identification of the effect of macroeconomic conditions on the probability of health insurance coverage comes from variation within people over time.

\section{Methods}

We first estimate a model in which the dependent variable indicates whether an individual has any health insurance coverage at a particular point in time. The empirical 
analysis is motivated by a random utility model. Suppose that each person derives utility based on insurance status; people enjoy utility $U_{I N S}$ if they are insured, and utility $U_{\text {UNINS }}$ if they are uninsured. The utility derived from being insured or uninsured depends upon individual characteristics $X$ and macroeconomic conditions $M$ :

$$
\begin{aligned}
& U_{I N S}=\alpha_{I N S}+X \beta_{I N S}+M \gamma_{I N S}+\varepsilon_{I N S} \\
& U_{U N I N S}=\alpha_{U N I N S}+X \beta_{U N I N S}+M \gamma_{U N I N S}+\varepsilon_{U N I N S}
\end{aligned}
$$

Macroeconomic conditions may affect the utility of being insured if, for example, it is more costly to acquire coverage when unemployment rates are high.

Let $y=1$ if the individual is insured and $y=0$ if the individual is uninsured. The probability that a person is insured is equal to the probability that utility in the insured state exceeds utility in the uninsured state.

$$
\begin{aligned}
& \operatorname{Pr}[y=1]=\operatorname{Pr}\left[U_{I N S}>U_{U N I N S}\right] \\
& \operatorname{Pr}[y=1]=\operatorname{Pr}\left[\left(\varepsilon_{I N S}-\varepsilon_{U N I N S}\right)>-\left(\alpha_{I N S}-\alpha_{U N I N S}\right)-X\left(\beta_{I N S}-\beta_{U N I N S}\right)-M\left(\gamma_{I N S}-\gamma_{U N I N S}\right)\right] \\
& \operatorname{Pr}[y=1]=\operatorname{Pr}[\varepsilon>-\alpha-X \beta-M \gamma]
\end{aligned}
$$

The distribution of the differenced error term determines the proper regression model to use to estimate the probability of health insurance coverage of individual $i$ living in state $s$ at time $t$ as a function of macroeconomic conditions $M$ and individual characteristics $X$. This paper assumes that the differenced error term follows a logistic distribution; as a result, logit regression models will be estimated of the form:

$$
y_{i s t}=\alpha+X_{i t} \beta+M_{s t} \gamma+\varepsilon_{i s t}
$$

The macroeconomic conditions $M$ that are examined include an indicator variable for national recession, state-level unemployment rates, and real per capita gross state product. We also control for individual-specific fixed effects and year-specific fixed 
effects. Individual characteristics $X$ include time-varying factors that may affect the person's probability of being uninsured, including age, marital status, education, and family size.

Models similar to equation (1) will be estimated for the following dependent variables: an indicator variable for whether one has health insurance coverage through any source, an indicator for whether one receives health insurance coverage through one's own employer, an indicator for whether the individual is covered by Medicaid or SCHIP, an indicator for whether the individual is covered by any government-provided health insurance ${ }^{15}$, an indicator for whether one's current employer offers health insurance, and an indicator for whether a worker offered health insurance by an employer has accepted that offer (i.e. health insurance "take-up").

The parameters of interest are the $\gamma$ coefficients, which will be used to measure the change in the probability that individuals are covered by health insurance associated with change in the macroeconomic variables. We hypothesize that the coefficients on variables for macroeconomic conditions will have the following sign, depending on the dependent variable (the source of the health insurance). Higher unemployment rate and national recession are assumed to decrease the probability of coverage through any source and decrease the probability of coverage through one's own employer. Higher gross state product is predicted to have the opposite effect, increasing the probability of coverage through any source or through one's own employer. We do not have unambiguous predictions about the signs of the coefficients on macroeconomic variables in the regressions for coverage through the government in general or through Medicaid or

\footnotetext{
${ }^{15}$ Government provided coverage for adults includes Medicare, Medicaid, other free or subsidized public assistance health insurance, or Armed Forces related health insurance provided by the government. For children, the list excludes Medicare since the SIPP did not ask about children's Medicare status.
} 
SCHIP in particular, because there are potentially offsetting effects. A poor

macroeconomy may increase the probability of coverage through the government if a person's income falls to a level that qualifies for Medicaid, or it may lead state legislatures to tighten eligibility requirements in order to decrease the rolls, or to reduce the generosity of benefits leading to lower take-up rates among the eligible population.

To determine the extent to which macroeconomic conditions affect health insurance coverage through all pathways, we first estimate model (1) without controlling for employment status. However, a change in employment is clearly one important path by which macroeconomic conditions affect health insurance, so we also re-estimate model (1) controlling for employment status, which allows us to determine the fraction of the overall correlation that is due to changes in employment.

\section{Data}

The relationship between state and national economic climate and individuals' health insurance status is measured using data from two nationally representative samples: the Survey of Income and Program Participation (SIPP) and the National Longitudinal Survey of Youth (NLSY). ${ }^{16}$ Each is well-suited for a study of health insurance and the macroeconomy because each follows the same individuals over a considerable period of time, permitting us to control for individual fixed effects. An advantage of the SIPP is its large sample size (we have samples of roughly three quarters of a million observations

\footnotetext{
${ }^{16}$ The Current Population Survey (CPS) is commonly used to assess the health insurance coverage of Americans. The advantages of the SIPP and NLSY over the CPS are that the SIPP and NLSY track individuals for long periods of time and that they record health insurance coverage at a particular point in time whereas the CPS is cross-sectional and records only whether the individual had health insurance coverage at any time in the past year. Bennefield (1996) finds that CPS respondents tend to underreport health insurance coverage relative to SIPP respondents.
} 
each for men, women, and children), and an advantage of the NLSY is its richer set of questions about health insurance. The SIPP serves as the primary dataset in this study, but when the SIPP lacks certain health insurance information we use that contained in the NLSY.

\section{4a. The Survey of Income and Program Participation}

The Survey of Income and Program Participation (SIPP) is a nationally representative sample of Americans over the age of $15^{17}$ that consists of a series of four-year panels starting in 1984 with sample sizes ranging from approximately 12,000 to 40,000 households. The SIPP interviews households at 4-month intervals (collecting data on the current month and, retrospectively, each of the three months between interviews) for up to 4 years; thus, we have up to 12 interviews for each individual.

Each wave contains information on the respondent's insurance coverage and the source of their coverage, for a particular month. We study the following outcomes in the SIPP: an indicator variable for whether one has health insurance coverage through any source, an indicator for whether one receives health insurance coverage through one's own employer, an indicator for whether the individual is covered by Medicaid or SCHIP, and an indicator for whether the individual is covered by any government-provided health insurance.

The SIPP also contains information on job status and demographic characteristics that may influence insurance status (e.g. age, race, gender, education, marital status, and family size). Publicly available state identifiers permit the merger of macroeconomic variables with the SIPP data. This paper uses data from the 1990-1996 panels of the

\footnotetext{
${ }^{17}$ There are also interview records for children in the household, based on parent's reports.
} 
SIPP covering the period 1990-2000. In order to avoid recall bias we do not use the retrospective data; we instead focus exclusively on data collected for the current month in which the respondent is interviewed. As a result, we have up to twelve observations for each individual in the SIPP.

The set of regressors used in each regression includes: highest grade completed, age, number of children in the family, marital status, indicator variables for each individual, and indicator variables for each year. We exclude income from the set of regressors because wages and salary are determined simultaneously with fringe benefits such as health insurance. Summary statistics of the SIPP data appear in Appendix Table 1A.

\section{4b. The National Longitudinal Survey of Youth}

The National Longitudinal Survey of Youth (NLSY) contains data from interviews of 12,686 respondents conducted annually from 1979 to 1994 and every two years from 1994 to 2000 . We study the following outcomes in the NLSY: an indicator variable for whether one's current employer offers health insurance (which is available for 1983-2000) and an indicator for whether the worker accepted (took up) that offer of coverage (which is available for 1989-2000).

Restricted-access geocodes permit the merger of macroeconomic variables with the NLSY data. The set of regressors used in each regression includes: indicator variables for individual, indicator variables for year, highest grade completed, age, family size, and indicator variables for marital status. Summary statistics of the NLSY data appear in Appendix Table 1B. 


\section{4c. Data on Macroeconomic Conditions}

The key explanatory variables that reflect the economic climate are an indicator variable for national recession, monthly state unemployment rate, and annual real per capita gross state product. We also include in our set of regressors a vector of indicator variables for year. The coefficients on these indicator variables capture the correlation of nationwide, year-specific macroeconomic conditions with changes in the probability of health insurance coverage.

The coding of the indicator variable for national recession is based on the business cycle peaks and troughs identified by the Business Cycle Dating Committee of the National Bureau of Economic Research (NBER). Recession is sometimes casually defined as two consecutive quarters of declining real Gross National Product, but the NBER defines recession as: "a period of significant decline in total output, income, employment, and trade, usually lasting from six months to a year, and marked by widespread contractions in many sectors of the economy." 18 The data used in this paper include the July 1990 to March 1991 recession.

The Bureau of Labor Statistics Local Area Unemployment Statistics Series is the source for monthly unemployment rates at the state level. Unemployment rate is a lagging indicator of recession. ${ }^{19}$ We control for individual and year fixed effects, so our identifying variation of unemployment on health insurance coverage is within people over time of deviations from the national mean for that year.

Data on gross state product are derived from the Regional Accounts Data collected by the Bureau of Economic Analysis of the U. S. Department of Commerce. We convert

\footnotetext{
${ }^{18}$ Public Information Office, National Bureau of Economic Research (2002).

${ }^{19}$ Business Cycle Dating Committee (2003).
} 
GSP to year 2000 dollars using the annual CPI-U. Real GSP is divided by Census estimates of the state population in that year. Since we control for individual and year fixed effects, our identifying variation of real per capita GSP on health insurance coverage is within people over time of deviations from the national mean for that year.

\section{4d. Additional State-Level Data}

We also include three regressors that control for heterogeneity at the state level. The first regressor is the percent of the workforce that is unionized in that state; Hirsch et al. (2001) is the source of this data. Unionization is relevant because unions are likely to negotiate health insurance coverage for their members.

Second, the Medicare Hospital Wage Index is used to proxy for differences in the cost of health insurance. The Social Security Act requires that CMS prospective payments to hospitals be adjusted for area differences in hospital wages; the Hospital Wage Index is used to make this adjustment. For each distinct labor market (based on Metropolitan Statistical Areas and statewide aggregates of rural areas), the weighted average hourly wage (AHW) is computed from the sum of the wage costs of all hospitals in that market divided by the sum of the hours worked in all hospitals in the market; the wage index value for a particular labor market equals the $\mathrm{AHW}$ for that market divided by the national AHW. We use the statewide rural area measure of the index because we know the state, but not county, of residence in the SIPP.

Finally, we control for variation across states and over time in the generosity of public health insurance programs like Medicaid and SCHIP using a simulated measure of public health insurance eligibility as in Currie and Gruber (1996). Specifically, we 
simulate the fraction of children under age 18 who would have been eligible for public health insurance had their families lived in a given state in a given year (after adjusting financial variables for inflation), using the 1990 Public Use Micro Sample (5 percent) of the Census. This produces an index that measures the generosity of public assistance health insurance in a given state in a given year.

\section{Empirical Results}

We initially estimate the probability that an individual has health insurance coverage as a function of macroeconomic conditions and basic demographic characteristics while excluding employment status, and then we re-estimate our models controlling for employment status in order to determine the proportion of the correlation explained by changes in employment. Each cell of each of our tables contains, from top to bottom, the logit fixed-effects coefficient, the $t$ statistic in parentheses, and the marginal effect italicized in square brackets. ${ }^{20}$

In measuring the correlation between insurance status and the macroeconomy one must first decide what aspects of the macroeconomy to examine. A naive approach would be to use an indicator variable for recession as the sole measure of the macroeconomy; this ignores variation in intensity of recession and changes in the macroeconomy when not in recession. We predict that recession is associated with a lower probability of coverage, but we find for both men and women that the coefficient on the recession indicator is not statistically significant in regressions concerning coverage through any source and coverage through one's employer. However, the

\footnotetext{
${ }^{20}$ Marginal effects are evaluated at the mean of the regressors in the sample. Given the number of observations in the SIPP sample, it was not computationally feasible to estimate marginal effects for each person in order to report the mean value of the marginal effect in the sample.
} 
probability that men and children are covered through government-provided insurance is negative and statistically significant. Men are 2.2 percent less likely, and children are 1.59 percent less likely, to be covered by the government during recession.

The null results for coverage through any source and coverage through an employer may be partly due to differences in health insurance and health care markets (such as the extent of mandated benefits) between the time of the recession in our data (1990-1991) and the more recent years in the data. However, the most likely explanation is that recession alone is an insufficient measure of the relevant macroeconomic dynamics that affect health insurance coverage. For example, because unemployment rate is a lagging indicator of recession, if unemployment rate is an important macroeconomic factor affecting health insurance coverage, coverage will trough after the recession is over. In short, recession may be an inaccurate measure of the meaningful ways in which the macroeconomy affects coverage. As a result, for the remainder of this paper we measure macroeconomic conditions using both state unemployment rate and real per capita gross state product.

Table 2 contains results for males in the SIPP. In the first row, our prediction that higher unemployment rates will be associated with a lower probability of coverage is confirmed for both coverage through any source and that through an individual's employer. The marginal effects indicate that a one percentage point increase in state unemployment rate is associated with a 0.7 percent decrease in the probability of any coverage for men. While this seems like a small effect, we show in the discussion section that this implies that more than 800,000 adult men lost coverage during the 2001 recession. 
The second row of Table 2 confirms our prediction that higher GSP is associated with a higher probability of coverage. A $\$ 1,000$ per capita increase in real GSP is associated with a 0.6 percent increase in the probability that a man has health insurance from any source.

We lacked predictions of the sign of the coefficients in regressions concerning government-provided coverage; the last column of Table 2 indicates that the coefficient on unemployment is not statistically significant, while that on GSP is positive and significant at the 10 percent level, the latter suggesting that government coverage works somewhat pro-cyclically for men.

Table 3 presents the analogous results for women. While coverage through any source is not sensitive to macroeconomic conditions for women, coverage through specific sources is. Specifically, the probability that a woman is covered through an employer is negatively correlated, and the probability that she is covered through Medicaid is positively correlated, with state unemployment rate. These results suggest that Medicaid operates counter-cyclically by enrolling women left uninsured by employers; the net result is that unemployment is uncorrelated with coverage. A one percentage point increase in unemployment rate decreases the probability of coverage through an employer by 0.78 percent, but raises the probability of coverage through Medicaid by 0.68 percent. It makes sense that Medicaid would operate more countercyclically for women than men given the gender difference in program eligibility.

Results for children are presented in Table 4 and they resemble those for adult women. Unemployment and real GSP are not correlated with the probability of coverage through any source, but unemployment rate is positively correlated with the probability 
of government coverage. Specifically, a one percentage point increase in unemployment is associated with a 1.04 percent increase in the probability a child is covered by Medicaid or SCHIP. ${ }^{21}$ A $\$ 1,000$ increase in real per capita GSP is associated with a 0.47 percent decrease in the probability of coverage through these public sources. These results likely reflect the counter-cyclical nature of Medicaid and SCHIP; when unemployment rates are high and children lose employer-provided health insurance because their parents have lost their jobs, SCHIP and Medicaid expand their coverage of children and the net effect is that the probability a child is covered through any source is uncorrelated with the unemployment rate.

One important way that the macroeconomy affects individuals' health insurance status is through their employment status (Bennefield, 1998). To determine how the macroeconomy correlates with the probability of employment, we regressed an indicator for current employment on the same set of regressors as earlier. The results, which are contained in Table 5, reveal that both women and men, are, predictably, less likely to be employed when state unemployment rates are high. A one percentage point rise in state unemployment is associated with a decrease in the probability of employment of 2.3 percent for men and a 1.11 percent for women. A $\$ 1,000$ increase in real per capita GSP is associated with an increase in the probability of employment of 1.13 percent for men and 0.33 percent for women. The marginal effects of both unemployment rate and GSP suggest that the employment of men is more pro-cyclical than that of women.

The NLSY contains certain information about health insurance options that is not available in the SIPP. For example, the NLSY asks respondents whether their employer

\footnotetext{
${ }^{21}$ The 1996 SIPP does not specifically ask about the State Children's Health Insurance Program (SCHIP) because of the timing of the survey versus SCHIP enactment, although children on SCHIP may be recorded under the Medicaid question in the latter part of the 1996 SIPP Panel.
} 
offered them health insurance coverage. It also asks whether they are currently covered by their own employer, which allows us to measure take-up of employer offers.

The correlation of employer offers of health insurance coverage with macroeconomic conditions for the sample of employed NLSY respondents is presented in Table $6{ }^{22}$ In addition to controlling for the earlier set of regressors, we also add an indicator for whether the employee is a part-time worker (defined as 35 hours a week or less). Employer offers to men are more sensitive to state unemployment rate than those to women; a one percentage point increase in unemployment rate is associated with a decrease in the probability that one's employer offers health insurance coverage of 0.28 percent for males and a 0.09 percent for females. This discrepancy is probably not due to employers having different policies toward the two genders, but is likely attributable to differences in occupation and sector or industry of occupation.

Cutler (2002) finds that employee take-up rates fell during the 1990s. We test for changes in take-up rates of employer-offered health insurance during periods of high unemployment. Specifically, we regressed an indicator variable for whether one receives health insurance coverage through one's own employer on macroeconomic variables for the sample of NLSY respondents who were both employed and offered health insurance coverage by their employer. The results are presented in Table 7. The coefficient on unemployment rate is statistically significant for women; a one percentage point increase in local unemployment rate is associated with a 3.12 percent increase in the probability of take-up for women; the results for men are not statistically significant at the 10 percent level. One story consistent with this gender discrepancy is that families tend to take up

\footnotetext{
${ }^{22}$ Note that the data on employer offers are at the employee level. As a result, large employers are likely to be over-represented in the data, biasing our estimates of the willingness of employers to offer health insurance.
} 
offers from the husband's employer, no matter what the macroeconomic conditions. When unemployment rates rise, husbands are less likely to have a job or be offered coverage, so wives are more likely to take up offers of coverage from their own employers. Our results are consistent with the hypothesis that an improved macroeconomy is one reason that take-up rates fell among women during the 1990s.

We next measure the extent to which macroeconomic conditions are correlated with insurance status conditional on employment status. Tables 8 and 9 are comparable to Tables 2 and 3 with the sole difference that indicator variables for employment and part-time employment have been added to the set of regressors. The coefficients on the indicator variables for employment and part-time employment are uniformly large and statistically significant, confirming that employment status has a large impact on the probability of coverage.

Tables 8 and 9 indicate that, even controlling for employment status, certain macroeconomic conditions remain correlated with the probability of health insurance coverage for men. In Table 2, before controlling for employment status, a one percentage point rise in unemployment was associated with a 0.7 percent decrease in the probability of health insurance coverage for men. In Table 8, after controlling for employment status, the associated decrease is 0.29 percent and this correlation is not statistically significant. Addition of the controls for employment and part-time employment lower the increase in the probability of any health insurance coverage associated with a $\$ 1,000$ increase in real per capita GSP from 0.6 percent to 0.48 percent, both of which are statistically significant. 
For men, unemployment rate remains statistically significant in regressions for coverage through an employer. Addition of the controls for employment and part-time employment lower the decrease in the probability of any health insurance coverage associated with a one point increase in the unemployment rate from 1.25 percent to 0.66 percent.

Our measures of the macroeconomy were not correlated with the probability of coverage through any source for women in Table 3, when we did not control for employment or part-time employment. However, unemployment is correlated with the probability of employer coverage for women in Table 3; specifically, a one-point increase in unemployment rate is associated with a 0.78 percent decrease in the probability of coverage through one's own employer. After controlling for employment in Table 9, a one-point increase in unemployment is associated with a 0.54 percent decrease in the probability of coverage through one's own employer; controlling for employment has reduced the correlation by about a third.

Overall, we conclude that employment status is a major pathway through which macroeconomic conditions affect the probability of health insurance coverage. Yet even after controlling for employment status, the macroeconomy still has a strong correlation with coverage through specific sources.

We conduct sensitivity checks to gauge the robustness of our findings. The results are not presented in table form in this paper but are available upon request.

We experimented with controlling for the employment rate instead of the unemployment rate. The first, but not the second, denominator includes people who are out of the labor force. We find that the coefficient on employment rate is statistically 
significant in the same regressions in which that on unemployment rate is statistically significant and that the absolute values are similar, although, predictably, the two have opposite signs.

In our primary results we use state-level unemployment rate. The restrictedaccess geocode for the NLSY allows us to merge county unemployment rates to the individual observations and thereby determine whether our results differ when we use a measure of unemployment from a smaller geographic area. We find very similar results when we use county rather than state unemployment rate in the NLSY regressions.

\section{Conclusion}

This paper measures the correlation between macroeconomic conditions and health insurance coverage. We control for both individual and year fixed effects, so our identifying variation is within people over time of deviations from the national mean for that year.

We find significant gender differences. For men, the probability of any health insurance coverage is negatively correlated with unemployment rate and positively correlated with real per capita gross state product. Specifically, a one percentage point increase in state unemployment rate is associated with a decrease in the probability of health insurance coverage through any source of 0.70 percent, and a $\$ 1,000$ increase in real per capita GSP is associated with an increase in the probability of coverage through any source of 0.6 percent. In contrast, neither of these macroeconomic measures is significantly correlated with coverage through any source for women or children. This difference in results between men, women, and children is likely due to Medicaid and 
SCHIP working counter-cyclically to enroll women and children who lose employerprovided coverage during periods of high unemployment.

Our prediction that an indicator variable for national recession would be negatively correlated with the probability of health insurance coverage was not supported by the data; in most cases the correlation is not statistically significant. This likely reflects the fact that unemployment rate is the most relevant aspect of the macroeconomy for health insurance status, and unemployment, as a lagging indicator of recession, tends to peak after recessions. Our finding may also be due to differences in health insurance and health care markets between the recession and more recent years in the data.

Employment status is correlated with both macroeconomic conditions and with the probability of health insurance coverage. Changes in employment status explain between a third and a half of the correlation between employer-provided health insurance coverage and unemployment rates for men and women. However, even after controlling for employment status, the macroeconomy still has a strong correlation with coverage through specific sources.

This paper also finds that employer offers of health insurance are sensitive to the unemployment rate; this correlation is stronger for men than women, likely reflecting gender differences in occupation and industry. Also, women (but not men) appear to be more likely to take up employer-offered health insurance when unemployment rates are high.

From March to November of 2001 the U.S. experienced an economic recession. We can use our estimates of the historic correlation between health insurance coverage and unemployment rate and GSP to predict the number of Americans who lost health 
insurance during the recession. During the 2001 recession, the national unemployment rate rose from 4.2 percent to 5.6 percent and real per capita GDP rose from $\$ 31,827$ to $\$ 31,892$. Based on these changes and our regression results, we estimate that roughly 851,000 Americans lost health insurance during the 2001 recession. Our estimates indicate that almost all of those who lost health insurance were adult men; specifically, that 827,000 of the 851,000 were men. Our estimate is less than that of Families USA (2002), which estimated that two million Americans lost health insurance due to increased unemployment between March and December of 2001. It should be kept in mind when comparing these estimates that that of Families USA was based on an extra month (December 2001) and was based on different data (CPS rather than SIPP). In addition, the Families USA study did not take into account the gain in health insurance coverage during the recession that occurred as a result of a slight rise in per-capita GSP.

Our estimates can also be used to estimate whether enough Americans have gained coverage during the current recovery to fully offset the loss of coverage during the recession. Between the end of the recession in November 2001 and August of 2003, the national unemployment rate rose from 5.6 percent to 6.1 percent and real per capita GDP rose from 31,892 to 33,191 . Based on these figures, we estimate that roughly 616,000 Americans gained health insurance coverage during the current recovery. This is less than the number of Americans we estimate lost coverage during the recession, suggesting that roughly 235,000 fewer Americans had health insurance coverage in August 2003 than had coverage in March 2001 when the recession began.

We emphasize that our estimates cover only those who lost (or gained) health insurance because of changes in the macroeconomy. Because of other changes in health 
insurance markets, labor markets, or society, additional people may have lost (or gained) health insurance during the periods we study, which is one factor to consider when comparing our estimates to recent Census estimates of the number of persons who lost health insurance for any reason during calendar years 2001 and 2002.

We stress that because the changes in probabilities of coverage are multiplied by a large number of Americans, small changes in parameter estimates can result in large changes in the estimates of Americans losing or gaining health insurance coverage. We encourage readers to focus on the larger conclusions that the macroeconomy (in particular, unemployment rate) is correlated with the probability of health insurance coverage, that this correlation is only partly explained by changes in employment status, that government-provided coverage for women and children is effectively countercyclical, and that more Americans likely lost health insurance during the 2001 recession than have gained it during the current recovery, than to assign great precision to the estimated number of Americans losing health insurance during recession or gaining it during the recovery.

We close with a caveat that caution should be used when estimates derived from the last decade are used to estimate the impact of the current recession. Several factors have changed that may affect the relationship between the macroeconomy and health insurance coverage. For example, more couples are dual-earner, suggesting that the impact of one spouse losing employer-provided health insurance may be less today than in the past. 


\section{References}

Bennefield, Robert L. 1996. "A Comparative Analysis of Health Insurance Coverage Estimates: Data from CPS and SIPP.” \#9608. (Bureau of the Census, U. S. Department of Commerce: Washington, DC).

Bennefield, Robert L. 1998. "Dynamics of Economic Well Being: Health Insurance 1993-1995. Who Loses Coverage and for How Long." Current Population Reports. August. (U. S. Census Bureau: Washington, D.C.).

Business Cycle Dating Committee, National Bureau of Economic Research. 2003. "The NBER's Business-Cycle Dating Procedure.” July 17.

Currie, Janet, and Jonathan Gruber. 1996. "Health Insurance Eligibility, Utilization of Medical Care, and Child Health." Quarterly Journal of Economics, 111: 431-66.

Cutler, David. 2002. "Employee Costs and the Decline in Health Insurance Coverage." NBER Working Paper \#9036.

Doty, Michelle M., and Cathy Schoen. 2001. "Maintaining Health Insurance During a Recession: Findings from The Commonwealth Fund 2001 Health Insurance Survey." Issue Brief. (The Commonwealth Fund: New York). December.

Doyle, Joseph J. 2001. "Does Health Insurance Affect Treatment Decisions \& Patient Outcomes? Using Automobile Accidents as Unexpected Health Shocks." Unpublished manuscript, University of Chicago.

Families USA. 2002. "2 Million Americans Lost Their Health Insurance in 2001: Largest One-Year Increase in Nearly a Decade.” Press release. February 12.

Gilmer, Todd, and Richard Kronick. 2001. "Calm Before the Storm: Expected Increase in the Number of Uninsured Americans." Health Affairs 20(6): 207-210.

Glied, Sherry, and Kathrine Jack. 2003. "Macroeconomic Conditions, Health Care Costs, and the Distribution of Health Insurance." NBER Working Paper \#10029.

Gruber, Jon, and Larry Levitt. 2002. "Rising Unemployment and the Uninsured." (Kaiser Family Foundation: Menlo Park, CA). January.

Barry T. Hirsch, David A. Macpherson, and Wayne G. Vroman. 2001. "Estimates of Union Density by State," Monthly Labor Review," 124(7): 51-55. July. (Accompanying data online at http://www.trinity.edu/bhirsch) Downloaded $12 / 2002$.

Holahan, John, and Bowen Garrett. 2001. "Rising Unemployment and Medicaid." Health Policy Online. October. http://www.urban.org/UploadedPDF/410306 HPOnline 1.pdf

Jacoby, Melissa B., Teresa A. Sullivan, and Elizabeth Warren. 2000. "Medical Problems and Bankruptcy Filings." Harvard Law School Public Law and Legal Theory Working Paper Series \#008, April.

$\mathrm{Ku}, \mathrm{L}$ and B. Garrett. 2000 "How Welfare Reform and Economic Factors Affected Medicaid Participation:1984-96." Assessing the New Federalism Discussion Paper, Number 00-01. (The Urban Institute: Washington, D.C.).

Lambrew, Jeanne M. 2001. "How the Slowing U.S. Economy Threatens EmployerBased Health Insurance." (The Commonwealth Fund: New York). November.

Levitt, K. C. Smith, C. Cowan, H. Lazenby, and A. Martin. 2002. "Inflation Spurs Health Spending in 2000." Health Affairs, 21(1): 172-181. 
Marquis, M. Susan, and Stephen H. Long. 2001. "Employer Health Insurance and Local Labor Market Conditions." International Journal of Health Care Finance and Economics, 1(3-4): 273-292.

Mills, Robert J. 2002. "Health Insurance Coverage: 2001." Current Population Reports. September. (U. S. Census Bureau: Washington, D.C.).

Mills, Robert J., and Shailesh Bhandari. 2003. "Health Insurance Coverage in the United States: 2002.” Current Population Reports. September. (U. S. Census Bureau: Washington, D.C.).

National Association of State Budget Officers. 2002. State Expenditure Report 2001. World wide web content. http://www.nasbo.org/Publications/PDFs/nasbo2001exrep.pdf

Pear, Robert and Robin Toner. 2002, "States Face Hard Choices on Medicaid Cuts" New York Times, January 14, p.1.

Public Information Office, National Bureau of Economic Research. 2002. "Business Cycle Expansions and Contractions." Press Release.

Rice, Thomas. 1999. "Subsidizing COBRA: An Option for Expanding Health Insurance Coverage" (Kaiser Foundation: Washington, D.C.).

Ruhm, Christopher J. 2003. "Good Times Make You Sick." Journal of Health Economics, 24(4): 637-658.

Ruhm, Christopher J. 2000. “Are Recessions Good for Your Health?” Quarterly Journal of Economics, 115(2): 617-650.

Weissman, J. S., C. Gastonis, and A. M. Epstein. 1992. "Rates of Avoidable Hospitalization by Insurance Status in Massachusetts and Maryland." Journal of the American Medical Association 268(17): 2388-2394. 


\section{Table 1 \\ SIPP}

\section{Whether Covered by Health Insurance as a Function of Current Recession Logit Fixed Effects Coefficients, t Statistics and Marginal Effects}

\begin{tabular}{cccc}
\hline Group & $\begin{array}{c}\text { Coverage } \\
\text { Through } \\
\text { Any Source }\end{array}$ & $\begin{array}{c}\text { Coverage } \\
\text { Through } \\
\text { Own } \\
\text { Employer }\end{array}$ & $\begin{array}{c}\text { Coverage } \\
\text { Through } \\
\text { Government }\end{array}$ \\
Men & -0.0082 & 0.0341 & -0.109 \\
N=731,749 & $(-0.29)$ & $(1.42)$ & $(-2.02)$ \\
& {$[-0.002]$} & {$[0.008]$} & {$[-0.022]$} \\
Women & 0.0168 & 0.0085 & -0.0128 \\
N=800,782 & $(0.59)$ & $(0.35)$ & $(-0.31)$ \\
& {$[0.004]$} & {$[0.002]$} & {$[-0.0032]$} \\
Children & 0.0247 & N.A. & -0.06352 \\
N=703,109 & $(0.84)$ & & $(-1.80)$ \\
& {$[0.000]$} & & {$[-0.0159]$} \\
\hline
\end{tabular}

Notes:

1) Logit coefficients appear first, with $t$ statistics in parentheses and marginal effects in italics underneath, in that order.

2) Data: pooled 1990-1996 waves of the SIPP. Sample includes all individuals between the ages of 17 and 64 years of age regardless of employment status. The children's regression contains individuals under 18 years of age.

3) Dependent variables: column 1: indicator variable that equals one if individual covered by health insurance from any source and zero otherwise; column 2: indicator variable that equals one if individual is covered by employer health insurance in own name and zero otherwise; column 3: indicator variable for any type of government provided health insurance. For children, this excludes Medicare. Government provided coverage for adults includes Medicare, Medicaid, other free or subsidized public assistance health insurance, or Armed Forces related health insurance provided by the government. For children, the list excludes Medicare since the SIPP did not ask about children's Medicare status.

4) Other regressors: Individual fixed effects, year fixed effects, Medicare hospital wage index, union coverage rate in the state, children's Medicaid generosity index of the state, highest grade completed, marital status, number of children in the family, and age. For the children's regression, the list excludes highest grade completed, marital status and number of children in the family. 
Table 2

SIPP Men

Whether Covered by Health Insurance

as a Function of Macroeconomic Conditions

Logit Fixed Effects Coefficients, t Statistics and Marginal Effects

\begin{tabular}{cccc}
\hline $\begin{array}{c}\text { Variable } \\
\text { Or Statistic }\end{array}$ & $\begin{array}{c}\text { Coverage } \\
\text { Through } \\
\text { Any Source }\end{array}$ & $\begin{array}{c}\text { Coverage } \\
\text { Through } \\
\text { Own } \\
\text { Employer }\end{array}$ & $\begin{array}{c}\text { Coverage } \\
\text { Through } \\
\text { Government }\end{array}$ \\
\hline State Unemployment & -.0286 & -0.0525 & -0.0138 \\
Rate & $(-3.19)$ & $(-6.91)$ & $(-0.91)$ \\
{$[-0.007]$} & {$[-0.0125]$} & {$[-0.0024]$} \\
Per Capita & 0.0241 & 0.0271 & 0.0178 \\
Real G.S.P. & $(3.11)$ & $(4.01)$ & $(1.67)$ \\
{$[0.006]$} & {$[0.0064]$} & {$[0.0032]$} \\
Mean of Dependent & 0.79 & 0.55 & 0.09 \\
Variable & & & \\
Number of & 731,749 & 731,749 & 731,749 \\
Observations & & & \\
\hline
\end{tabular}

Notes:

1) Data: pooled 1990-1996 waves of the SIPP. Sample includes all men between the ages of 17 and 64 years of age regardless of employment status.

2) Dependent variables: column 1: indicator variable that equals one if individual covered by health insurance from any source and zero otherwise; column 2: indicator variable that equals one if individual is covered by employer health insurance in own name and zero otherwise; column 3: indicator variable for any type of government provided health insurance. Government provided coverage includes Medicare, Medicaid, other free or subsidized public assistance health insurance, or Armed Forces related health insurance provided by the government.

3) Other regressors: Individual fixed effects, year fixed effects, Medicare hospital wage index, union coverage rate in the state, children's Medicaid generosity index of the state, highest grade completed, marital status, number of children in the family, and age. 


\section{Table 3 \\ SIPP Women \\ Whether Covered by Health Insurance \\ as a Function of Macroeconomic Conditions \\ Logit Fixed Effects Coefficients, t Statistics and Marginal Effects}

\begin{tabular}{|c|c|c|c|c|}
\hline $\begin{array}{c}\text { Variable } \\
\text { Or Statistic }\end{array}$ & $\begin{array}{c}\text { Coverage } \\
\text { Through Any } \\
\text { Source }\end{array}$ & $\begin{array}{c}\text { Coverage } \\
\text { Through } \\
\text { Own } \\
\text { Employer }\end{array}$ & $\begin{array}{l}\text { Coverage } \\
\text { Through } \\
\text { Medicaid }\end{array}$ & $\begin{array}{c}\text { Coverage } \\
\text { Through } \\
\text { Government }\end{array}$ \\
\hline $\begin{array}{c}\text { State } \\
\text { Unemployment } \\
\text { Rate }\end{array}$ & $\begin{array}{c}-0.00112 \\
(-0.12) \\
{[-0.0003]}\end{array}$ & $\begin{array}{c}-0.0345 \\
(-4.44) \\
{[-0.0078]}\end{array}$ & $\begin{array}{c}0.039 \\
(2.97) \\
{[0.0068]}\end{array}$ & $\begin{array}{c}-0.0062 \\
(-0.54) \\
{[-0.0015]}\end{array}$ \\
\hline $\begin{array}{l}\text { Per Capita } \\
\text { Real G.S.P. }\end{array}$ & $\begin{array}{c}0.0094 \\
(1.29) \\
{[0.0023]}\end{array}$ & $\begin{array}{c}-0.002 \\
(-0.33) \\
{[-0.0004]}\end{array}$ & $\begin{array}{c}-0.0217 \\
(-2.1) \\
{[-0.0038]}\end{array}$ & $\begin{array}{c}-0.0034 \\
(-0.40) \\
{[-0.0008]}\end{array}$ \\
\hline $\begin{array}{l}\text { Mean of } \\
\text { Dependent } \\
\text { Variable }\end{array}$ & 0.77 & 0.37 & 0.10 & 0.14 \\
\hline $\begin{array}{l}\text { Number of } \\
\text { Observations }\end{array}$ & 800,782 & 800,782 & 800,782 & 800,782 \\
\hline
\end{tabular}

Notes:

1) Data: pooled 1990-1996 waves of the SIPP. Sample includes all women between the ages of 17 and 64 years of age regardless of employment status.

2) Dependent variables: column 1: indicator variable that equals one if individual covered by health insurance from any source and zero otherwise; column 2: indicator variable that equals one if individual is covered by employer health insurance in own name and zero otherwise; column 3 : indicator variable for Medicaid coverage; column 4: indicator variable for any type of government provided health insurance. Government provided coverage includes Medicare, Medicaid, other free or subsidized public assistance health insurance, or Armed Forces related health insurance provided by the government.

3) Other regressors: Individual fixed effects, year fixed effects, Medicare hospital wage index, union coverage rate in the state, children's Medicaid generosity index of the state, highest grade completed, marital status, number of children in the family, and age. 


\section{Table 4}

SIPP

Whether Child Has Health Insurance Coverage as a Function of Macroeconomic Conditions Logit Fixed Effects Coefficients, $t$ Statistics and Marginal Effects

\begin{tabular}{|c|c|c|c|}
\hline $\begin{array}{c}\text { Variable } \\
\text { Or Statistic }\end{array}$ & $\begin{array}{c}\text { Coverage } \\
\text { Through } \\
\text { Any Source }\end{array}$ & $\begin{array}{c}\text { Coverage } \\
\text { Through } \\
\text { Medicaid or } \\
\text { SCHIP }\end{array}$ & $\begin{array}{c}\text { Coverage } \\
\text { Through } \\
\text { Government }\end{array}$ \\
\hline $\begin{array}{c}\text { State } \\
\text { Unemployment Rate }\end{array}$ & $\begin{array}{l}0.0098 \\
(1.07) \\
{[0.000]}\end{array}$ & $\begin{array}{c}0.0416 \\
(4.02) \\
{[0.0104]}\end{array}$ & $\begin{array}{c}0.0321 \\
(3.29) \\
{[0.0079]}\end{array}$ \\
\hline $\begin{array}{l}\text { Per Capita } \\
\text { Real G.S.P. }\end{array}$ & $\begin{array}{c}0.0102 \\
(1.24) \\
{[0.000]}\end{array}$ & $\begin{array}{c}-0.0190 \\
(-2.20) \\
{[-0.0047]}\end{array}$ & $\begin{array}{c}0.0004 \\
(0.05) \\
{[0.0001]}\end{array}$ \\
\hline $\begin{array}{c}\text { Mean of Dependent } \\
\text { Variable }\end{array}$ & 0.684 & 0.190 & 0.217 \\
\hline $\begin{array}{l}\text { Number of } \\
\text { Observations }\end{array}$ & 703,109 & 703,109 & 703,109 \\
\hline
\end{tabular}

Notes:

1) Data: pooled 1990-1996 waves of the SIPP. Sample includes all children under the age of 18.

2) Dependent variables: column 1: indicator variable that equals one if child covered by any health insurance from any source and zero otherwise; column 2: indicator variable that equals one if child covered by Medicaid or SCHIP and zero otherwise; column 3: indicator variable that equals one if child has government-provided health insurance coverage and zero otherwise. Government provided coverage includes Medicaid, other free or subsidized public assistance health insurance, or Armed Forces related health insurance provided by the government. The list excludes Medicare since the SIPP did not ask about children's Medicare status.

3) Other regressors: Individual fixed effects, year fixed effects, Medicare hospital wage index, union coverage rate in the state, children's Medicaid generosity index of the state, and age. 


\section{Table 5 \\ SIPP}

Whether Currently Employed

as a Function of Macroeconomic Conditions

\section{Logit Fixed Effects Coefficients, $t$ Statistics and Marginal Effects}

\begin{tabular}{ccc}
\hline $\begin{array}{c}\text { Variable } \\
\text { Or Statistic }\end{array}$ & Men & Women \\
& & \\
\hline State & -0.0926 & -0.0449 \\
Unemployment Rate & $(-11.58)$ & $(-6.33)$ \\
& {$[-0.023]$} & {$[-0.0111]$} \\
& 0.0455 & 0.0134 \\
Per Capita & $(5.65)$ & $(2.32)$ \\
Real G.S.P. & {$[0.0113]$} & {$[0.0033]$} \\
& 0.802 & 0.657 \\
Mean of & & \\
Dependent Variable & & \\
Number of & 731,749 & 800,782 \\
Observations & & \\
\hline
\end{tabular}

Notes:

1) Data: pooled 1990-1996 waves of the SIPP. Sample includes all individuals between the ages of 17 and 64 years of age regardless of employment status.

2) Dependent variable equals one if employed during the survey month and zero otherwise.

3) Other regressors: Individual fixed effects, year fixed effects, Medicare hospital wage index, union coverage rate in the state, children's Medicaid generosity index of the state, highest grade completed, marital status, number of children in the family, and age. 
Table 6

NLSY

Whether Current Employer Offers Health Insurance as a Function of Macroeconomic Conditions Logit Fixed Effects Coefficients, t Statistics, and Marginal Effects

\begin{tabular}{ccc}
\hline $\begin{array}{c}\text { Variable } \\
\text { Or Statistic }\end{array}$ & Men & Women \\
\hline State & -.0549 & -.0223 \\
Unemployment Rate & $(-4.66)$ & $(-1.70)$ \\
& {$[-.0028]$} & {$[-.0009]$} \\
Per Capita & .0046 & .0116 \\
Real G.S.P. & $(0.76)$ & $(1.64)$ \\
& {$[.0002]$} & {$[.0005]$} \\
Part-Time & -1.349 & -.1 .250 \\
Worker & $(-27.21)$ & $(-31.46)$ \\
& {$[-.0693]$} & {$[-.0510]$} \\
Mean of & .76 & .76 \\
Dependent Variable & & \\
Number of & 33,206 & 27,759 \\
Observations & & \\
& & \\
\hline
\end{tabular}

Notes:

1) Data: 15 pooled years of the NLSY. Sample includes only those currently employed.

2) Dependent variable equals one if current employer offers health insurance coverage and zero otherwise.

3) Marginal probabilities are computed using the sample means of the regressors.

4) Other regressors: Individual fixed effects, year fixed effects, Medicare hospital wage index, highest grade completed, age, family size, and indicator variables for marital status. 
Table 7

NLSY

Whether Employee Takes Up Employer Offer of Health Insurance as a Function of Macroeconomic Conditions

Logit Fixed Effects Coefficients, $t$ Statistics, and Marginal Effects

\begin{tabular}{ccc}
\hline $\begin{array}{c}\text { Variable } \\
\text { Or Statistic }\end{array}$ & Men & Women \\
\hline State & -.0248 & .0613 \\
Unemployment Rate & $(-.77)$ & $(1.79)$ \\
& {$[.0039]$} & {$[.0312]$} \\
Per Capita & -.0003 & -.0090 \\
Real G.S.P. & $(-.02)$ & $(-.60)$ \\
& {$[-.0001]$} & {$[-.0033]$} \\
Part-Time & -.4788 & -.6243 \\
Worker & $(-3.56)$ & $(-6.86)$ \\
& {$[-.0752]$} & {$[-.1118]$} \\
Mean of & .85 & .76 \\
Dependent Variable & & \\
Number of & 8,992 & 8,669 \\
Observations & & \\
& &
\end{tabular}

Notes:

1) Data: 15 pooled years of the NLSY. Sample includes only those currently employed.

2) Dependent variable equals one if current employer offers health insurance coverage and zero otherwise.

3) Marginal probabilities are computed using the sample means of the regressors.

4) Other regressors: Individual fixed effects, year fixed effects, Medicare hospital wage index, highest grade completed, age, family size, and indicator variables for marital status. 
Table 8

SIPP Men

Whether Covered by Health Insurance

as a Function of Macroeconomic Conditions and Employment Status

Logit Fixed Effects Coefficients, $t$ Statistics, and Marginal Effects

\begin{tabular}{|c|c|c|c|}
\hline $\begin{array}{c}\text { Variable } \\
\text { Or Statistic }\end{array}$ & $\begin{array}{c}\text { Coverage } \\
\text { Through } \\
\text { Any Source }\end{array}$ & $\begin{array}{c}\text { Coverage } \\
\text { Through } \\
\text { Own } \\
\text { Employer }\end{array}$ & $\begin{array}{c}\text { Coverage } \\
\text { Through } \\
\text { Government }\end{array}$ \\
\hline $\begin{array}{c}\text { State Unemployment } \\
\text { Rate }\end{array}$ & $\begin{array}{c}-0.0116 \\
(-1.28) \\
{[-0.0029]}\end{array}$ & $\begin{array}{c}-0.0291 \\
(-3.62) \\
{[-0.0066]}\end{array}$ & $\begin{array}{c}-0.0316 \\
(-2.05) \\
{[-0.0057]}\end{array}$ \\
\hline $\begin{array}{l}\text { Per Capita } \\
\text { Real G.S.P. }\end{array}$ & $\begin{array}{c}0.0195 \\
(2.5) \\
{[0.0048]}\end{array}$ & $\begin{array}{c}0.0184 \\
(2.66) \\
{[0.0042]}\end{array}$ & $\begin{array}{c}0.0247 \\
(2.27) \\
{[0.0044]}\end{array}$ \\
\hline $\begin{array}{l}\text { Indicator: } \\
\text { Employed }\end{array}$ & $\begin{array}{c}0.3761 \\
(20.71) \\
{[0.0930]}\end{array}$ & $\begin{array}{c}0.9651 \\
(50.04) \\
{[0.2204]}\end{array}$ & $\begin{array}{c}-0.7077 \\
(-22.00) \\
{[-0.1268]}\end{array}$ \\
\hline $\begin{array}{c}\text { Indicator: } \\
\text { Part-Time Worker }\end{array}$ & $\begin{array}{c}-0.6587 \\
(-36.37) \\
{[-0.1628]}\end{array}$ & $\begin{array}{c}-1.7287 \\
(-89.38) \\
{[-0.3949]}\end{array}$ & $\begin{array}{c}0.7113 \\
(21.66) \\
{[0.1274]}\end{array}$ \\
\hline $\begin{array}{c}\text { Mean of Dependent } \\
\text { Variable }\end{array}$ & 0.79 & 0.55 & 0.09 \\
\hline $\begin{array}{l}\text { Number of } \\
\text { Observations }\end{array}$ & 731,749 & 731,749 & 731,749 \\
\hline
\end{tabular}

Notes:

1) Data: pooled 1990-1996 waves of the SIPP. Sample includes all men between the ages of 17 and 64 years of age regardless of employment status.

2) Dependent variables: column 1: indicator variable that equals one if individual covered by health insurance from any source and zero otherwise; column 2: indicator variable that equals one if individual is covered by employer health insurance in own name and zero otherwise; column 3: indicator variable for any type of government provided health insurance. Government provided coverage includes Medicare, Medicaid, other free or subsidized public assistance health insurance, or Armed Forces related health insurance provided by the government.

3) Other regressors: Individual fixed effects, year fixed effects, Medicare hospital wage index, percent unionization in state, children's Medicaid eligibility index, highest grade completed, marital status, presence of children in the family, and age. 


\section{Table 9 \\ SIPP Women \\ Whether Covered by Health Insurance \\ as a Function of Macroeconomic Conditions and Employment Status \\ Logit Fixed Effects Coefficients, t Statistics, and Marginal Effects}

\begin{tabular}{|c|c|c|c|c|}
\hline $\begin{array}{c}\text { Variable } \\
\text { Or Statistic }\end{array}$ & $\begin{array}{c}\text { Coverage } \\
\text { Through Any } \\
\text { Source }\end{array}$ & $\begin{array}{c}\text { Coverage } \\
\text { Through } \\
\text { Own } \\
\text { Employer }\end{array}$ & $\begin{array}{l}\text { Coverage } \\
\text { Through } \\
\text { Medicaid }\end{array}$ & $\begin{array}{c}\text { Coverage } \\
\text { Through } \\
\text { Government }\end{array}$ \\
\hline $\begin{array}{c}\text { State } \\
\text { Unemployment } \\
\text { Rate }\end{array}$ & $\begin{array}{c}0.0047 \\
(0.52) \\
{[0.0011]}\end{array}$ & $\begin{array}{c}-0.0234 \\
(-2.76) \\
{[-0.0054]}\end{array}$ & $\begin{array}{c}0.0182 \\
(1.34) \\
{[0.0030]}\end{array}$ & $\begin{array}{c}-0.0240 \\
(-2.06) \\
{[-0.006]}\end{array}$ \\
\hline $\begin{array}{l}\text { Per Capita } \\
\text { Real G.S.P. }\end{array}$ & $\begin{array}{c}0.0087 \\
(1.2) \\
{[0.0021]}\end{array}$ & $\begin{array}{c}-0.0048 \\
(-0.74) \\
{[-0.0011]}\end{array}$ & $\begin{array}{c}-0.0210 \\
(-2.00) \\
{[-0.0035]}\end{array}$ & $\begin{array}{c}-0.0014 \\
(-0.16) \\
{[-0.0003]}\end{array}$ \\
\hline $\begin{array}{l}\text { Indicator: } \\
\text { Employed }\end{array}$ & $\begin{array}{c}0.1259 \\
(7.18) \\
{[0.0301]}\end{array}$ & $\begin{array}{c}1.275 \\
(64.88) \\
{[0.292]}\end{array}$ & $\begin{array}{c}-0.9753 \\
(-36.70) \\
{[-0.1604]}\end{array}$ & $\begin{array}{c}-0.8698 \\
(-36.96) \\
{[-0.2163]}\end{array}$ \\
\hline $\begin{array}{l}\text { Indicator: } \\
\text { Part-Time } \\
\text { Worker }\end{array}$ & $\begin{array}{l}-0.4683 \\
(-27.25) \\
{[-0.112]}\end{array}$ & $\begin{array}{c}-1.827 \\
(-104.62) \\
{[-0.418]}\end{array}$ & $\begin{array}{c}0.8604 \\
(31.07) \\
{[0.1415]}\end{array}$ & $\begin{array}{c}0.7412 \\
(30.50) \\
{[0.1844]}\end{array}$ \\
\hline $\begin{array}{l}\text { Mean of } \\
\text { Dependent } \\
\text { Variable }\end{array}$ & 0.77 & 0.37 & 0.10 & 0.14 \\
\hline $\begin{array}{l}\text { Number of } \\
\text { Observations }\end{array}$ & 800,782 & 800,782 & 800,782 & 800,782 \\
\hline
\end{tabular}

Notes:

1) Data: pooled 1990-1996 waves of the SIPP. Sample includes all women between the ages of 17 and 64 years of age regardless of employment status.

2) Dependent variables: column 1: indicator variable that equals one if individual covered by health insurance from any source and zero otherwise; column 2: indicator variable that equals one if individual is covered by employer health insurance in own name and zero otherwise; column 3 : indicator variable for Medicaid coverage; column 4: indicator variable for any type of government provided health insurance. Government provided coverage includes Medicare, Medicaid, other free or subsidized public assistance health insurance, or Armed Forces related health insurance provided by the government.

3) Other regressors: Individual fixed effects, year fixed effects, Medicare hospital wage index, highest grade completed, children's Medicaid generosity index of the state, marital status, number of children in the family, and age. 


\section{Appendix Table 1A Summary Statistics of SIPP Data}

\begin{tabular}{lccccc}
\hline \multicolumn{1}{c}{ Variable } & $\begin{array}{c}\text { Number of } \\
\text { Observations }\end{array}$ & Mean & $\begin{array}{c}\text { Standard } \\
\text { Deviation }\end{array}$ & Minimum & Maximum \\
\hline Indicator: covered by own employer HI & $1,532,531$ & 0.460 & 0.498 & 0 & 1.0 \\
Indicator: covered by any HI & $1,532,531$ & 0.846 & 0.36 & 0 & 1.0 \\
Indicator: covered by Medicaid & $1,532,531$ & 0.069 & 0.253 & 0 & 1.0 \\
Indicator: covered by government HI & $1,532,531$ & 0.115 & 0.319 & 0 & 1.0 \\
Indicator: national recession & $1,532,531$ & 0.061 & 0.239 & 0 & 1.0 \\
State unemployment rate & $1,532,531$ & 5.942 & 1.704 & 1.9 & 12.80 \\
Hospital wage index & $1,329,731$ & 8232.01 & 952.08 & 4080 & 12456 \\
Per capita real gross state product & $1,532,531$ & 24.08 & 6.33 & 11.54 & 104.01 \\
State Medicaid generosity & $1,532,531$ & .30 & 0.102 & 0.114 & .797 \\
Union coverage & $1,532,531$ & 17.22 & 6.70 & 3.8 & 31.89 \\
Indicator: female & $1,532,531$ & 0.522 & 0.499 & 0 & 1.0 \\
Year & $1,532,531$ & 1994.4 & 2.84 & 1990 & 2000 \\
Indicator: High-school dropout & $1,532,531$ & 0.163 & 0.369 & 0 & 1.0 \\
Indicator: High-school graduate & $1,532,531$ & 0.333 & 0.471 & 0 & 1.0 \\
Indicator: Some college & $1,532,531$ & 0.281 & 0.449 & 0 & 1.0 \\
Indicator: College graduate & $1,532,531$ & 0.128 & 0.334 & 0 & 1.0 \\
Age & $1,532,531$ & 38.666 & 12.48 & 18 & 64 \\
Number of children in family & $1,532,531$ & 0.903 & 1.187 & 0 & 12 \\
Indicator: employed & $1,532,531$ & 0.726 & 0.446 & 0 & 1.0 \\
Indicator: employer part time & $1,532,531$ & 0.386 & 0.486 & 0 & 1.0 \\
Indicator: married & $1,532,531$ & 0.596 & 0.490 & 0 & 1.0 \\
Indicator: widowed & $1,532,531$ & 0.022 & 0.148 & 0 & 1.0 \\
Indicator: separated or divorced & $1,532,531$ & 0.129 & 0.334 & 0 & 1.0 \\
Indicator: child covered by any HI & 703,109 & 0.86 & 0.34 & 0 & 1.0 \\
Indicator: child covered by government HI & 703,109 & 0.217 & 0.412 & 0 & 1.0 \\
\hline
\end{tabular}

Notes:

1) The sample for all but the last two items consists of adults (age 18-64). The sample for the last two items is all children under age 18 . 
Appendix Table 1B:

Summary Statistics of NLSY Data

\begin{tabular}{lccccc}
\hline \multicolumn{1}{c}{ Variable } & $\begin{array}{c}\text { Number of } \\
\text { Observations }\end{array}$ & Mean & $\begin{array}{c}\text { Standard } \\
\text { Deviation }\end{array}$ & Minimum & Maximum \\
\hline Indicator: employer offers HI & 102,135 & .743 & .44 & 0 & 1 \\
Indicator: took up employer offer of HI & 56,179 & .592 & .49 & 0 & 1 \\
Indicator: national recession & 102,135 & .077 & .27 & 0 & 1 \\
State unemployment rate & 102,135 & 6.44 & 2.21 & 1.7 & 21.6 \\
Medicare Hospital Wage Index & 81,080 & 8409.09 & 958.67 & 4089 & 14870 \\
State Medicaid generosity & 102,135 & 17.86 & 7.46 & 4.4 & 36.3 \\
Union coverage & 102,135 & .231 & .115 & .028 & .769 \\
Indicator: female & 102,135 & .469 & .50 & 0 & 1 \\
Indicator: black & 102,135 & .267 & .44 & 0 & 1 \\
Indicator: Hispanic & 102,135 & .173 & .38 & 0 & 1 \\
Year & 102,135 & 199.48 & 4.81 & 1983 & 2000 \\
Highest grade completed & 102,135 & 12.94 & 2.33 & 0 & 20 \\
Age & 102,135 & 29.42 & 5.27 & 18 & 44 \\
Family size & 102,135 & 3.05 & 1.67 & 1 & 15 \\
Indicator: employed & 102,135 & .930 & .26 & 0 & 1 \\
Indicator: married, spouse present & 102,135 & .481 & .50 & 0 & 1 \\
Indicator: other marital status & 102,135 & .154 & .36 & 0 & 1 \\
\hline
\end{tabular}

